\title{
PELAKSANAAN KEGIATAN PENGENDALIAN PENYAKIT PNEUMONIA PADA BALITA DI WILAYAH KERJA PUSKESMAS I PURWOKERTO TIMUR TAHUN 2018
}

(ditinjau dari sisi surveilans, determinan, dan upaya pengendalian)

\author{
Siti Hidayatul Majidah ${ }^{1)}$, Aris Santjaka ${ }^{2)}$ \\ Jurusan Kesehatan Lingkungan, Politeknik Kesehatan Kemenkes Semarang, \\ Jl.Raya Baturaden KM 12 Purwokerto, Indonesia
}

\begin{abstract}
Abstrak
Pada tahun 2015 WHO melaporkan hampir enam juta anak balita meninggal dunia dan $16 \%$ dari jumlah tersebut disebabkan oleh pneumonia sebagai pembunuh balita nomor satu di dunia. Pneumonia adalah penyakit pernapasan yang masih menjadi masalah kesehatan masyarakat. Pada tahun 2016 ditemukan 3.005 kasus Pneumonia yang terjadi di kabupaten Banyumas. Pneumonia ini banyak terjadi di wilayah Purwokerto Timur, yang ditemukan 274 kasus. Tujuan utama dari penelitian ini adalah untuk memberikan gambaran pelaksanaan kegiatan pengendalian penyakit Pneumonia pada balita yang ditinjau dari sisi surveilans, determinan dan upaya pengendalian. Metode penelitian yang digunakan adalah penelitian deskriptif. Subyek Penelitian yaitu petugas puskesmas dan 20 penderita pneumonia. Pengumpulan data umum dan data khusus dengan wawancara, obsevasi, dan pengukuran di lapangan. Pada tahun 2015 hingga 2017 cakupan penemuan penderita pneumonia balita belum bisa mencapai target. Hasil penelitian didapatkan jumlah penderita Pneumonia terdiri dari laki-laki 11 orang (55\%) dan perempuan 9 orang (45\%). Penyakit Pneumonia kebanyakan terjadi pada kelompok umur 1-5 tahun. Penderita Pneumonia kebanyakan terjadi pada penderita yang memiliki rumah dengan kondisi ventilasi yang tidak memenuhi syarat dan kondisi pencahayaan yang tidak memenuhi syarat. Penderita terbanyak pada wilayah Arcawinangun dengan 13 kasus dan puncak kejadian Pneumonia terjadi pada bulan April yaitu 5 orang (25\%). Berdasarkan hasil penelitian untuk menanggulangi penyakit Pneumonia, puskesmas lebih meningkatkan cakupan penemuan penderita Pneumonia dan untuk masyarakat apabila membangun rumah atau merenovasi rumah perlu memperhatikan aspek rumah sehat dan memberikan balita imunisasi yang lengkap.
\end{abstract}

Kata Kunci

: Surveilans, Determinan, Pengendalian Pneumonia

\begin{abstract}
Implementation of Pneumonia Diseases Control Activities in Toddlers in The Region of Puskesmas I East Purwokerto Year 2018 (directed by surveillance, determinants and control efforts). By 2015 the WHO reports nearly six million children under five die and $16 \%$ of that number is caused by pneumonia as the number one killer of children under five in the world. Pneumonia is a respiratory disease that is still a public health problem. In 2016 found 3,005 cases of Pneumonia that occurred in Banyumas district. Pneumonia is a lot of happening in East Purwokerto area, which found 274 cases. The main purpose of this study is to provide an overview of the implementation of Pneumonia disease control activities in under-five children in terms of surveillance, determinants and control efforts. The research method was the descriptive method and the subjects were puskesmas office and 20 patients with Pneumonia. The general and specific data was collected through interview, observation, and field measurement. By 2015 until 2017 pneumonia sufferer detection coverage could not reach the target. The research result shows Pneumonia patient consist from 11 men (55\%) and 19 women (45\%). Pneumonia commonly occur toward 1-5 years old group of age. Pneumonia sufferers mostly occur in patients who have homes that do not meet the conditions of ventilation and lighting conditions that do not meet the requirements. The highest number of patients in the Arcawinangun area was 13 patients and the peak incidence of pneumonia occurred in April, ie 5 people (25\%). Based on research, in addition to overcome Pneumonia, Puskesmas further increase the sufferer detection of Pneumonia's discovery and for the society if they will build a house or will renovate the house need to pay attention to the aspect of healthy house and provide a complete immunization toddler.
\end{abstract}

Keywords

: Surveilance, Determinant, Pneumonia Control 


\section{PENDAHULUAN}

Tujuan pembangunan kesehatan menuju Indonesia Sehat 2025 adalah meningkatnya kesadaran, kemauan, dan kemampuan hidup sehat bagi setiap orang. Peningkatan derajat kesehatan masyarakat yang setinggi-tingginya dapat terwujud, melalui terciptanya masyarakat, bangsa dan negara Indonesia. Ditandai oleh penduduknya yang hidup dengan perilaku dan dalam lingkungan sehat, memiliki kemampuan untuk menjangkau pelayanan kesehatan yang bermutu, secara adil dan merata, serta memiliki derajat kesehatan yang setinggi-tingginya di seluruh wilayah Republik Indonesia (RPJPK 2005-2025, h. 33).

Menurut Hendrik L. Blum derajat kesehatan masyarakat di pengaruhi empat faktor utama yaitu faktor lingkungan, perilaku manusia, pelayanan kesehatan dan keturunan. Keempat faktor tersebut saling berinteraksi yang mempengaruhi kesehatan perorangan dan derajat kesehatan masyarakat. Faktor sosial, teknologi, dan lingkungan yang terus memberikan efek pada penyakit menular di berbagai belahan dunia, memfasilitasi kemunculan penyakit baru dan penyakit lama yang muncul kembali, sering kali dalam bentuk patogen yang resisten terhadap antibiotik. Kondisi ekologi dan demografi modern yang menunjang penyebaran penyakit menular meliputi pertumbuhan populasi yang pesat, peningkatan angka kemiskinan, dan urbanisasi, perubahan habitat hewan dan arthropoda yang dapat menularkan penyakit, dan perubahan dalam proses dan distribusi makanan (Centers for Disease control and Prevention, 1998).

Penyakit menular merupakan penyakit yang ditularkan melaui berbagai media. Penyakit jenis ini merupakan masalah yang besar di hampir semua negara berkembang karena angka kesakitan dan kematiannya yang relatif tinggi dalam waktu yang relatif singkat, berbeda dengan penyakit tidak menular yang biasanya bersifat menahun dan banyak disebabkan oleh gaya hidup. Penyakit menular umumnya bersifat akut (mendadak) dan menyerang semua lapisan masyarakat. Penyakit jenis ini masih diprioritaskan mengingat sifat menularnya bisa menyebabkan wabah dan menimbulkan kerugian yang besar.

Penyakit menular pada hakikatnya timbul oleh adanya interaksi, antara faktor-faktor yang berkaitan dengan manusia sebagai pejamu (Host), kuman penyebab (Agent) dan lingkungan (Environment). Melihat kenyataan tersebut maka metode pemberantasan penyakit menular sangat tergantung epidemiologi dari masing-masing penyakit. Pemberantasan penyakit menular merupakan upaya dibidang kesehatan untuk menghilangkan atau mengubah cara berpindahnya penyakit infeksi dari orang yang satu kepada orang lainya atau dari binatang ke manusia. Penularan atau perpindahan penyakit merupakan suatu cara bagaimana orang atau infeksi dari orang lain atau dari hewan yang sakit ataupun yang sehat tetapi membawa penyakit.

Diantara beberapa penyakit yang kerap menjangkit, infeksi saluran pernapasan (ISPA) merupakan penyakit berbahaya yang kerap menderita anak-anak. Data WHO telah mencatat bahwa ISPA adalah salah satu penyakit yang banyak menyebabkan kematian pada anak. ISPA merupakan penyebab kematian anak yang paling umum di negara berkembang. Hampir semua kematian karena ISPA pada anak adalah akibat ISPA bagian bawah terutama Pneumonia.

Tahun 2015 WHO melaporkan hampir enam juta anak balita meninggal dunia dan $16 \%$ dari jumlah tersebut disebabkan oleh pneumonia sebagai pembunuh balita nomor satu di dunia. Di Indonesia Pneumonia merupakan penyebab dari $15 \%$ kematian balita, penemuan pneumonia pada balita tahun 2017 sebesar 870.893 dan realisasi penemuan penderita pneumonia balita sebesar 503.738 atau 57.84\%. Pneumonia pada anak balita di negara berkembang termasuk Indonesia disebabkan oleh Pneumococcus dan Hib (Haempphilus influenza type b) (Profil Kesehatan Indonesia tabel 6.9, 2017).

Penemuan dan penanganan penderita pneumonia pada balita di Jawa Tengah Tahun 2015 sebesar $53,31 \%$ dengan 52.842 kasus, meningkat cukup signifikan dibandingkan capaian tahun 2014 yaitu 26,11\% dengan 71.451 kasus (Profil Kesehatan Provinsi Jawa Tengah, tabel 10). Peningkatan yang cukup besar ini disebabkan sasaran atau perkiraan penderita pada tahun 2014 adalah $10 \%$ dari jumlah balita. Sedangkan pada tahun 2016 sebesar 17,49\% dengan 20,662 kasus, jumlah kasus menurun dibandingkan kasus pada tahun 2015 (Profil Kesehatan Jawa Tengah, 2016).

Salah satu wilayah di provinsi Jawa Tengah yang banyak ditemukan kasus pneumonia adalah daerah Kabupaten Banyumas. Di Kabupaten Banyumas tahun 2016 sebesar 27,82\% dengan 3.005 kasus, hal ini sedikit meningkat bila dibanding tahun 2015 sebesar 27,55\% dengan 2.762 kasus. Menurut data dari Dinas Kesehatan Kabupaten Banyumas tahun 2016, Puskesmas I Purwokerto Timur merupakan salah satu daerah yang banyak ditemukan kejadian pneumonia. Berdasarkan data dari pencatatan dan pelaporan tahun 2016 jumlah penderita yang dilaporkan yaitu sebanyak 274 penderita pneumonia balita, dengan 139 penderita laki-laki dan 135 penderita perempuan.

Wilayah Purwokerto timur merupakan daerah perkotaan yang dengan mudah masyarakat dapat mengakses pelayanan kesehatan sehingga 
orang tua yang memiliki Balita yang terkena ISPA dapat langsung dibawa ke pelayanan kesehatan, namun biasanya orang tua akan membawa balitanya ke pelayanan kesehatan ketika sakit ISPA sudah berlangsung lama hingga lebih dari 14 hari sehingga disaat itulah ada keterlambatan dalam penanganan dan upaya pencegahan terhadap penyakit Pneumonia. Melihat keadaan inilah penulis tertarik untuk menulis tugas akhir dengan Judul "Pelaksanaan Kegiatan Pengendalian Penyakit Pneumonia Pada Balita Di Wilayah Puskesmas I Purwokerto Timur Tahun 2018 (ditinjau dari sisi surveilans, determinan, dan upaya pengendalian)".

Tujuan dari penelitian ini yaitu mengetahui pelaksanaan pengendalian penyakit pneumonia pada balita di wilayah Puskesmas I Purwokerto Timur kecamatan Purwokerto Timur yang ditinjau dari sisi surveilans, determinan dan upaya pengendalian.

\section{BAHAN DAN METODE DATA UMUM}

Jenis pelaksanaan Karya Tulis Ilmiah ini adalah deskriptif yang bertujuan memberikan gambaran mengenai pelaksanaan kegiatan pengendalian penyakit pneumonia pada balita. Subjek penelitian ini adalah petugas puskesmas pemegang program pengendalian ISPA dan pendeita pneumonia yaitu 20 penderita yang terdapat di wilayah kerja Puskesmas I Purwokerto Timur yaitu Kelurahan Mersi, Arcawinangun dan Purwokerto Wetan.

Data kasus pneumonia pada balita diambil dari registrasi penyakit di Puskesmas I Purwokerto Timur dan dinyatakan menderita pneumonia berdasarkan diagnosis klinis oleh dokter. Beberapa variabel penelitan ini adalah kepadatan hunian rumah, suhu rumah, kelembaban rumah, pencahayaan rumah, jenis lantai, luas ventilasi.

Penelitian ini dilakukan dengan wawancara, pengukuran, dan observasi lingkungan fisik rumah balita. Analisis data dalam penelitian ini adalah analisis tabel.

\section{HASIL DAN PEMBAHASAN}

Penelitian ini dilaksanakan di wilayah kerja Puskesmas I Purwokerto Timur yang terdiri dari 3 Kelurahan yaitu Mersi, Arcawinangun dan Purwokerto Wetan. Jumlah penduduk di wilayah kerja Puskesmas I Purwokerto Timur berjumlah 58.403 jiwa, yang terdiri dari Lakilaki 28.579 Jiwa dan Perempuan 29.824 Jiwa. Dibandingkan luas wilayah daerah terpadat tahun ini adalah kelurahan Arcawinangun dengan kepadatan $8.612,34$ penduduk $/ \mathrm{km}^{2}$ mengalami peningkatan sebesar 333, disusul kelurahan Purwokerto Wetan $7.624,30$ penduduk $/ \mathrm{km}^{2}$ dan kelurahan Mersi $5.442,31$ penduduk $/ \mathrm{km}^{2}$. Jika dibandingkan kepadatan rata-rata di kabupaten Banyumas angka ini tergolong tinggi.

Struktur penduduk di wilayah kerja Puskesmas I Purwokerto Timur Tahun 2017 Jika dilihat menurut komposisi menurut umur, jumlah penduduk terbanyak adalah usia 15-44 tahun dengan komposisi 13.960 jiwa laki-laki dan 13.936 jiwa perempuan. Komposisi penduduk pada kecamatan Purwokerto Timur paling banyak adalah usia produktif dengan jenis kelamin lakilaki

\section{DATA KHUSUS}

\section{A. Gambaran survailans epidemiologi Pneumonia \\ Pengumpulan Data}

Pengumpulan data secara pasif yang didapatkan dari Puskesmas dan Puskesmas Pembantu.

Pengumpulan data secara aktif yang didapatkan berdasarkan survey-survey penderita yang dilakukan oleh petugas puskesmas.

\section{Pengolahan Data dan Analisi data}

Berdasarkan hasil wawancara yang telah dilakukan di Puskesmas I Purwokerto Timur diketahui bahwa pengolahan data yang dilakukan oleh petugas kesehatan masih berupa data mentah yang bersumber dari daftar register (kunjungan pasien, lapangan, pustu, dan laporan masyarakat). Selanjutnya, data tersebut direkapitulas, diolah, dan di ringakas menjadi tabel dan grafik sebagai berikut :

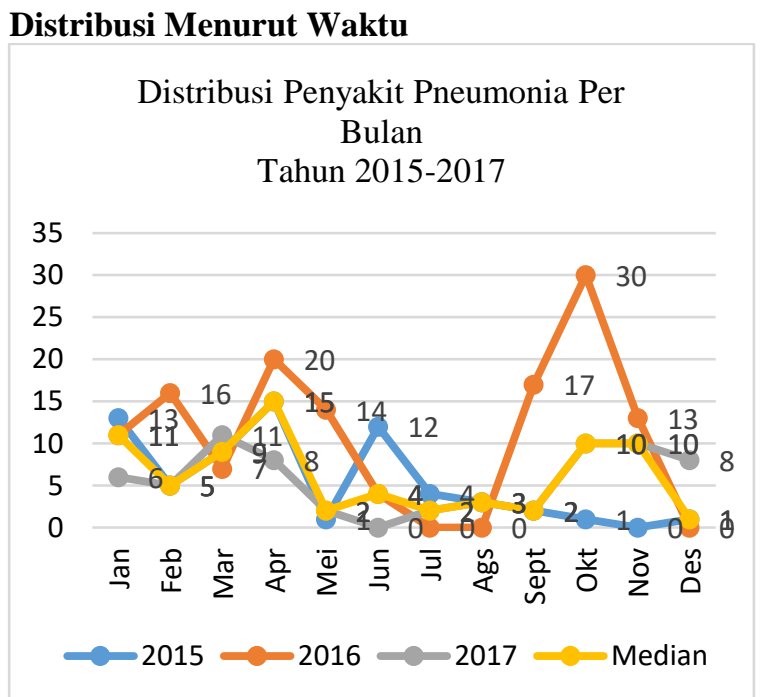

Grafik 4.1 Distribusi Penderita Pneumonia menurut waktu Di Wilayah Kerja Puskesmas I Purwokerto Timur Tahun 2015-2017

Terlihat pola Perkembangan jumlah kasus ditahun 2015-2016 dimana rata-rata kasus perbulannya sebanyak 8 kasus dengan kasus maksimal terjadi pada bulan Oktober 2016 
sebanyak 30 kasus dan kasus minimnal terjadi dibulan November 2015, bulan Juli, Agustus, September 2016 dan bulan Juni 2017 sebanyak 0 kasus. Pola perkembangan ditahun 2015-2016 menjadi dasar untuk melakukan survailans epidemiologi Pneumonia ditahun 2017. Data penyakit Pneumonia dari bulan Januari sampai Desember 2017 dapat terlihat pada gambar atau dapat menunjukkan bahwa penyakit Pneumonia dapat terkendali, selalu berada dibawah ratarata walau sedikit terlihat ada kecenderungan naik.

\section{Distribusi Menurut Tempat}

Distribusi Penderita Pneumonia Menururt Tempat Tahun 2015-2017

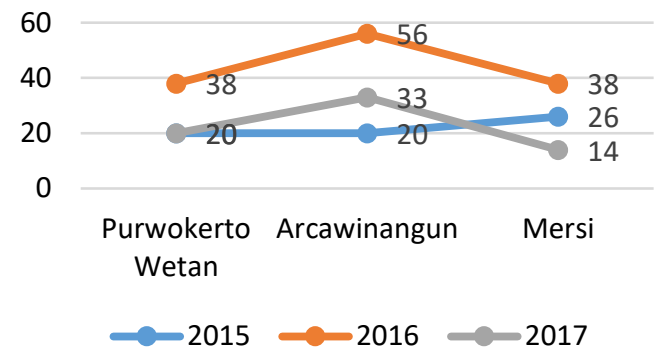

Grafik 4.2 Distribusi Frekuensi Penderita Pneumonia menurut tempat Di Wilayah Kerja Puskesmas I Purwokerto Timur Tahun 2015-2017 Terlihat pola distribusi Pneumonia menurut tempat yang ditunjukkan seperti pada grafik 4.2 Wilayah-wilayah dengan kasus terbanyak ini terdapat pada kelurahan Arcawinangun sebanyak 56 kasus tahun 2016 dan wilayah dengan kasus terendah yaitu pada kelurahan Mersi sebanyak 14 kasus pada tahun 2017.

\section{Distribusi Menurut Orang}

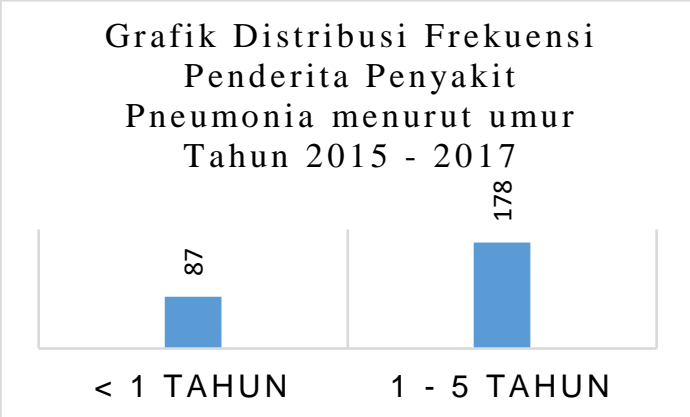

Grafik 4.3 Distribusi Frekuensi Penderita Pneumonia menurut umur Di Wilayah Kerja Puskesmas I Purwokerto Timur Tahun 2015-2017

Kelompok umur penderita Pneumonia seperti di tunjukkan pada grafik 4.3 bahwa dari data tahun 2015-2017 di wilayah kerja Puskesmas Purwokerto Timur yang paling banyak ditemukan kasus Pneumonia pada balita yang memiliki umur 1-5 tahun yaitu 178 kasus $(67,1 \%)$ dan pada balita dengan umur $<1$ tahun terdapat 87 kasus $(32,8 \%)$.

\section{Penyebarluasan Informasi (Desiminasi) dan Umpan Balik}

Penyebarluasan informasi dan umpan balik meliputi cara penyebarluasan informasi, pelaporan data ke DKK (ketepatan waktu dan kelengkapan laporan), keterlibatan lintas program/ sektor, dan hal-hal yang menghambat pelaksanaan surveilans penyakit Pneumonia.

\section{Rekomendasi dan Alternatif Tindak Lanjut}

Pencegahan kesakitan Pneumonia pada golongan usia balita (1-5 tahun) masih perlu ditingkatkan.

Di Puskesmas I Purwokerto Timur diperlukan peningkatan mutu pelayanan sehingga kesakitan yang disebabkan oleh penyakit pneumonia yang pada dasarnya dapat dicegah dapat dihindari.

\section{Sumber Data}

Register penderita berobat jalan

Pada saat penderita melakukan pemeriksaan sebelumnya mengisi Buku Register yang di dalamnya mencatat nama, umur, jenis kelamin, alamat, diagnosa penyakit dan keterangan lainnya.

Hasil penyelidikan / kegiatan lapangan

Hasil penyelidikan lapangan yang telah dilakukan oleh petugas program pengendalian akan dimasukkan dan dijadikan salah satu sumber informasi.

Data cakupan program

Data cakupan program pengendalian penyakit ISPA, data cakupan Imunisasi, dan sebagainya dapat digunakan untuk analisa program pengendalian ispa yang dapat dikaitkan dengan penyakit tersebut.

Data umum

Data umum yang dapat dijadikan data pendukung untuk melakukan program pengendalian meliputi data penduduk, data geografi, data curah hujan dan lainnya. Data umum ini dapat diperoleh dikantor Kecamatan atau Kantor Kabupaten.

\section{Kelengkapan, Ketepatan dan Kebenaran Laporan}

Kelengkapan laporan yang dari masingmasing wilayah kerja Puskesmas I Purwokerto Timur bahwa kelurahan Mersi kelengkapan laporan sebesar 61,82\%, kelurahan Arcwinangun 67, 17\% dan kelurahan Purwokerto Wetan yaitu $71,35 \%$. Dari ke 3 kelurahan di atas belum mencapai target kelengkapan laporan.

Ketepatan Waktu laporan yang dari masing-masing wilayah kerja Puskesmas I Purwokerto Timur bahwa kelurahan Mersi lebih banyak memberikan laporan dengan ketepatan waktu yang terlambat, kelurahan Arcawinangun lebih banyak tidak lapor dan kelurahan Purwokerto Wetan dalam tahun 2017 tidak melaporkan kejadian Pneumonia. 
Data yang dimuat dalam Laporan merupakan data yang benar dan dapat dipertanggung jawabkan (Valid).

\section{B. Gambaran Determinan Lingkungan Penyakit Pneumonia}

Variabel menurut Orang

Tabel 4.4 Distribusi Frekuensi Penderita Pneumonia Menurut Jenis Kelamin

\begin{tabular}{lcc}
\hline Jenis kelamin & $\begin{array}{c}\text { Jumlah } \\
\text { (orang) }\end{array}$ & Persentase (\%) \\
\hline Laki-laki & 11 & 55 \\
Perempuan & 9 & 45 \\
\hline Jumlah & 20 & $100 \%$ \\
\hline \multicolumn{2}{c}{ Rasio penderita Pneumonia menurut jenis }
\end{tabular}

kelamin yaitu penderita laki-laki sebanyak $55 \%$ dan jumlah penderita perempuan sebanyak $45 \%$. Seperti ditunjukkan pada tabel 4.4 di atas dapat diasumsikan bahwa menurut Depkes RI, 2004 menunjukkan anak laki-laki adalah faktor resiko yang mempengaruhi kesakitan Pneumonia.

Tabel 4.5 Distribusi Frekuensi Penderita Pneumonia Menurut Umur

\begin{tabular}{lcc}
\hline Umur & $\begin{array}{c}\text { Jumlah } \\
\text { (orang) }\end{array}$ & Persentase (\%) \\
\hline$<1$ Tahun & 1 & 5 \\
$1-5$ Tahun & 19 & 95 \\
\hline Jumlah & 20 & $100 \%$ \\
\hline
\end{tabular}

Rasio penyakit pneumonia menurut umur $>1-5$ tahun yaitu 95\% dibandingkan dengan umur $<1$ tahun yaitu $5 \%$, seperti ditunjukkan pada tabel 4.5 diketahui bahwa dapat diasumsikan golongan umur 1-5 tahun lebih beresiko terkena Pneumonia, karena golongan umur tersebut memiliki daya tahan tubuh rendah. Saat bayi lahir, dia mendapatkan zat kekebalan tubuh dari ibunya dan kekebalan tubuh dari ibu akan menurun dan menghilang seiring bertambahnya usia.

Tabel 4.6 Distribusi Frekuensi Penderita Pneumonia Menurut Pendidikan KK

\begin{tabular}{lcc}
\hline $\begin{array}{c}\text { Tingkat } \\
\text { Pendidikan }\end{array}$ & $\begin{array}{c}\text { Jumlah } \\
\text { (orang) }\end{array}$ & Persentase (\%) \\
\hline Perguruan & 1 & 5 \\
Tinggi & 8 & 40 \\
SMA/MA & 9 & 45 \\
SMP/MTs & 2 & 10 \\
SD/MI & 20 & $100 \%$ \\
\hline Jumlah & & \\
\hline
\end{tabular}

Tingkat pendidikan kepala keluarga penderita pneumonia seperti ditunjukkan pada tabel 4.6 diatas bahwa pendidikan kepala keluarga terbanyak adalah dengan tingkat pendidikan SMP/MTs yaitu 9 orang (45\%), sedangkan Perguruan Tinggi yaitu 1 orang $(5 \%)$. Pendidikan formal yang dicapai dapat membantu untuk memberi dan memahami pesan-pesan penyuluhan khususnya informasi tentang kesehatan.

Tabel 4.7 Distribusi Frekuensi Penderita Pneumonia Menurut Status Imunisasi

\begin{tabular}{lcc}
\hline \multicolumn{1}{c}{$\begin{array}{c}\text { Status } \\
\text { imunisasi }\end{array}$} & $\begin{array}{c}\text { Jumlah } \\
\text { (orang) }\end{array}$ & Persentase (\%) \\
\hline $\begin{array}{l}\text { Lengkap } \\
\text { Tidak } \\
\text { lengkap }\end{array}$ & 18 & 90 \\
\hline \multicolumn{1}{c}{ Jumlah } & 2 & 10 \\
\hline
\end{tabular}

Status Imunisasi penderita Pneumonia seperti ditunjukkan pada tabel 4.7 di atas dapat diketahui persentase status imunisasi yang lengkap 18 orang (90\%), lebih besar jika dibandingkan yang tidak lengkap 2 orang (10\%).

Tabel 4.8 Distribusi frekuensi kekambuhan Pneumonia pada balita

\begin{tabular}{lcc}
\hline Kekambuhan & $\begin{array}{c}\text { Jumlah } \\
\text { (orang) }\end{array}$ & $\begin{array}{c}\text { Persentase } \\
(\%)\end{array}$ \\
\hline Kambuh & 3 & 15 \\
Tidak & 17 & 85 \\
Kambuh & 20 & $100 \%$ \\
\hline Jumlah & & \\
\hline
\end{tabular}

Dari 3 responded di atas yang mengalami kekambuhan berjenis kelamin laki-laki dengan umur responden 1 dan 2 berumur 4 tahun serta responden 3 berumur 3,9 tahun. Dilihat dari faktor lingkungan fisik yang berperan yaitu tidak memenuhinya persyaratan ventilasi, responden 1 luas ventilasi hanya $8,9 \%$, responden 2 dan 3 luas ventilasi kamar yaitu 8,3\%. Ventilasi kamar dari 3 responden di atas tidak memenuhi syarat ditambah dengan responden 1 memiliki suhu udara rumah tidak memenuhi syarat dan responden 2 memiliki pencahayaan rumahnya tidak memenuhi syarat.

Tabel 4.10 Distribusi Frekuensi Perilaku Merokok Dalam Keluarga

\begin{tabular}{lcc}
\hline $\begin{array}{c}\text { Perilaku merokok } \\
\text { dalam keluarga }\end{array}$ & $\begin{array}{c}\text { Jumlah } \\
\text { (orang) }\end{array}$ & $\begin{array}{c}\text { Persentase } \\
(\%)\end{array}$ \\
\hline Ada & 8 & 40 \\
Tidak Ada & 12 & 60 \\
\hline Jumlah & 20 & $100 \%$ \\
\hline
\end{tabular}

Perilaku merokok dalam keluarga seperti ditunjukkan tabel 4.9 di atas bahwa dari 20 responden, diketahui jumlah penderita Pneumonia yang tinggal di rumah dengan perilaku merokok dalam keluarga yang tidak memenuhi syarat 
sebanya 8 rumah (40\%) dan yang memenuhi syarat sebanyak 12 rumah $(60 \%)$. Menurut Permenkes RI No 1077/Menkes/Per/V/2011 tentang pedoman penyehatan udara dalam ruang rumah, Environmental Tobacco Smoke (ETS) dapat memperparah gejala anak-anak penderita asma, Senyawa dalam asap rokok menyebabkan kanker paru pada manusia, bersifat iritan yang kuat bagi Bayi dan anak-anak.

Variabel Menurut Tempat

Kejadian balita pneumonia paling banyak terjadi di kelurahan Arcawinangun yang merupakan desa tertinggi jumlah penduduknya. Jumlah penderita Pneumonia di kelurahan Arcawinangun sebanyak 13 kasus (65\%) dan paling sedikit terdapat pada kelurahan Purwkerto Wetan yaitu sebanyak 2 kasus (10\%). Kelurahan Arcawinangun merupakan kelurahan dengan penduduk terpadat di wilayah kerja Puskesmas I Purwokerto Timur sehinggan penyakit Pneumonia dapat mudah menular pada daerah tersebut.

Variabel Menurut Waktu

Pola perkembangan kasus pneumonia per bulan, dapat diketahui bahwa kejadian Pneumonia Paling tinggi terjadi pada bulan April yaitu 5 orang $(25 \%)$, dan paling sedikit pada bulan Juli dan November yaitu 1 orang (5\%). Sedanglan bulan Desember terdapat 4 orang (20\%), bulan Januari terdapat 3 orang $(15 \%)$ dan pada bulan Februari, Mei dan September masing-masing terdapat 2 orang (10\%). Hal ini terjadi kemungkinan ada kaitannya dengan musim sehingga pada bulan April terjadi peningkatan jumlah penderita Pneumonia.

Kondisi Lingkungan Fisik Rumah Penderita Pneumonia

Gambaran Jenis Lantai Rumah Penderita Pneumonia

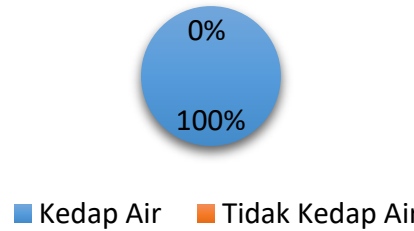

Gambar 4.2 Diagram Jenis lantai rumah Penderita Pneumonia

Keseluruhan responden memiliki jenis lantai rumah yang sudah memenuhi syarat seperti ditunjukkan pada gambar 4.3. di atas bahwa semua jenis lantai rumah penderita Pneumonia di Wilayah Puskesmas I Purwokerto Timur adalah kedap air dengan persentase 100\% (20 rumah).
Gambaran Luas Ventilasi Rumah Penderita Pneumonia

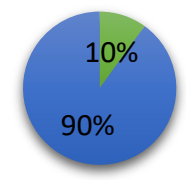

Memenuhi Syarat $\square$ Tidak Memenuhi Syarat

Gambar 4.3 Diagram luas ventilasi rumah Penderita Pneumonia

Seperti ditunjukkan pada gambar 4.4 di atas bahwa persentase rumah dengan luas ventilasi yang memenuhi syarat 10\% (2 rumah), lebih sedikir dibandingkan dengan rumah yang tidak memenuhi syarat 90\% (18 rumah). Menurut Permenkes RI No 1077/Menkes/Per/V/2011 tentang pedoman penyehatan udara dalam ruang rumah, luas ventilasi yang memenuhi syarat yaitu minimal $10 \%$ dari luas lantai.

Tabel 4.12 Distribusi Frekuensi Suhu udara rumah penderita Pneumonia

\begin{tabular}{|c|c|c|}
\hline Suhu Udara & Jumlah & $\begin{array}{l}\text { Persentase } \\
(\%)\end{array}$ \\
\hline $\begin{array}{ll}\text { Memenuhi } & \text { Syarat } \\
\left(18^{\circ} \mathrm{C}-30^{\circ} \mathrm{C}\right) & \end{array}$ & 14 & 70 \\
\hline $\begin{array}{l}\text { Tidak Memenuhi } \\
\text { Syarat }\left(<18^{\circ} \mathrm{C} \text { atau }\right. \\
\left.>30^{\circ} \mathrm{C}\right)\end{array}$ & 6 & 30 \\
\hline Jumlah & 20 & $100 \%$ \\
\hline
\end{tabular}

Seperti ditunjukkan pada tabel 4.11 di atas bahwa dari 20 responden, diketahui jumlah responden yang Suhu udaranya memenuhi syarat yaitu sebanyak 14 rumah $(70 \%)$ dan rumah yang Suhue udaranya tidak memenuhi syarat sebanyak 6 rumah (30\%). Menurut Permenkes No. 1077 tahun 2011 tentang pedoman penyehatan udara dalam ruang rumah, Kualitas udara di dalam rumah tidak boleh melebihi ketentuan dimana Suhu udara nyaman berkisar antara $18^{\circ} \mathrm{C}-30^{\circ} \mathrm{C}$.

Tabel 4.13 Distribusi Frekuensi Pencahayaan rumah penderita Pneumonia

\begin{tabular}{lcc}
\hline \multicolumn{1}{c}{ Pencahayaan } & Jumlah & $\begin{array}{c}\text { Persentase } \\
(\%)\end{array}$ \\
\hline $\begin{array}{l}\text { Memenuhi Syarat }(60 \\
\text { Lux) }\end{array}$ & 4 & 20 \\
$\begin{array}{l}\text { Tidak Memenuhi } \\
\text { Syarat (<60 lux atau } \\
>60 \text { lux) }\end{array}$ & 16 & 80 \\
\hline Jumlah & 20 & $100 \%$ \\
\hline
\end{tabular}

Seperti ditunjukkan pada tabel 4.12 di atas bahwa dari 20 responden, diketahui jumlah rumah responden yang memiliki Pencahayaan yang memenuhi syarat sebanyak 4 rumah $(20 \%)$ dan jumlah rumah responden yang Pencahayaannya tidak memenuhi syarat sebanyak 16 rumah (80\%). 
Menurut Permenkes No. 1077 tahun 2011 tentang pedoman penyehatan udara dalam ruang rumah, pencahayaan minimal untuk rumah sehat adalah 60 lux

Tabel 4.14 Distribusi Frekuensi Kelembaban Udara Rumah penderita Pneumnia

\begin{tabular}{|c|c|c|}
\hline Kelembaban Udara & Jumlah & $\begin{array}{l}\text { Persentase } \\
(\%)\end{array}$ \\
\hline $\begin{array}{l}\text { Memenuhi } \\
(40 \%-60 \%)\end{array}$ & 19 & 95 \\
\hline \begin{tabular}{lll} 
Tidak & \multicolumn{2}{c}{ Memenuhi } \\
Syarat & $(<40 \%$ atau \\
$>60 \%)$ & &
\end{tabular} & 1 & 5 \\
\hline Jumlah & 20 & $100 \%$ \\
\hline
\end{tabular}

Seperti ditunjukkan pada tabel 4.13 di atas bahwa dari 20 responden, diketahui jumlah rumah responden dengan kelembaban udara yang memenuhi syarat sebanyak 19 rumah $(95 \%)$ dan jumlah rumah responden yang tidak memenuhi syarat sebanyak 1 rumah (5\%). Menurut Permenkes No. 1077 tahun 2011 tentang pedoman penyehatan udara dalam ruang rumah, persyaratan kelembaban berkisar antara 40\%$60 \%$.

Tabel 4.15 Distribusi Frekuensi Penggunaan Bahan Bakar penderita Pneumonia

\begin{tabular}{lcc}
\hline $\begin{array}{c}\text { Penggunaan bahan } \\
\text { bakar }\end{array}$ & Jumlah & $\begin{array}{c}\text { Persent } \\
\text { ase (\%) }\end{array}$ \\
\hline $\begin{array}{l}\text { Memenuhi Syarat (gas) } \\
\text { Tidak Memenuhi Syarat } \\
\text { (kayu bakar) }\end{array}$ & 18 & 90 \\
\hline Jumlah & 20 & $100 \%$ \\
\hline
\end{tabular}

Bahan bakar dibagi menjadi dua kategori yaitu memenuhi syarat jika responden mengguakan bahan bakar berupa gas dan tidak memenuhi syarat jika responden menggunakan bahan bakar berupa arang atau kayu bakar. Seperti ditunjukkan pada tabel 4.14 di atas bahwa dari 20 responden, diketahui jumlah responden yang tinggal di rumah dengan penggunaan bahan bakar yang memenuhi syarat sebanyak 18 rumah (90\%) dan penggunaan bahan bakar yang tidak memenuhi syarat sebanyak 2 rumah $(10 \%)$.

\section{Gambar Kepadatan Penghuni Rumah Penderita Pneumonia}

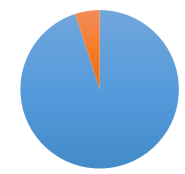

Normal Padat

Gambar 4.1 Diagram Kepadatan Penghuni

Kepadatan penghuni rumah penderita Pneumonia seperti ditunjukkan pada gambar 4.2 di atas bahwa kepadatan penghuni rumah yang normal sebesar 95\% (19 rumah), sedangkan rumah dalam kategori padat sebesar 5\% (1 rumah) dari 20 rumah yang dilakukan pengukuran. Menurut KEPMENKES RI NO 829 / MENKES / SK / VII 1999 tentang persyaratan kesehatan perumahan, luas ruang tidur minimal 8 meter dan tidak dianjurkan digunakan lebih dari 2 orang tempat tidur dalam satu ruang tidur kecuali anak di bawah umur 5 tahun.

\section{Gambaran Upaya Pengendalian Penyakit Pneumonia \\ Puskesmas}

Pencegahan dan pemberantasan penyakit Pneumonia balita Berdasarkan data dari petugas ISPA Puskesmas I Purwokerto Timur tahun 2017 sebanyak 61 kasus, yang ditemukan dan ditangani sebanyak 61 kasus (100\%). Dalam rangka melakukan pencegahan penyakit Pneumonia, Puskesmas melakukan beberapa kegiatan diantaranya sebagai berikut :

Penyuluhan kesehatan kepada masyarakat

Petugas program pengendalian ISPA bekerjasama dengan bidang promkes, membuat program kerja yaitu melakukan penyuluhan kesehatan kepada masyarakat setiap satu bulan satu kali.

Penyuluhan kepada ibu balita yang terkena Pneumonia

Puskesmas melakukan penyuluhan kepada ibu balita, hal ini dilakukan oleh petugas medis yang melakukan tindakan terhadap balita sekaligus memberikan penyuluhan kepada ibu balita mengenai penyakit Pneumonia dan pencegahannya.

Melakukan pengobatan terhadap penderita yang terkena Pneumonia

Petugas medis memberikan pengobatan terhadap penderita pneumonia guna untuk mendapatkan penyembuhan terhadap penyakit pneumonia.

Melakukan perbaikan gizi dan imunisasi pada bayi dan balita.

Upaya pencegahan merupakan komponen strategis dalam pemberantasan Pneumonia melalui imunisasi yang dilakukan pihak puskesmas meliputi pemberian imunisasi DPT dan campak yang telah dilaksanakan dapat menurunkan proporsi kematian balita akibat Pneumonia. Perbaikan gizi dan imunisasi pada bayi dan balita dilakukan oleh petugas puskesmas dalam kegiatan posyandu.

\section{Masyarakat}

Keluarga atau rumah tangga adalah unit masyarakat terkecil. Oleh sebab itu untuk mencapai derajat kesehatan masyarakat yang baik harus dimulai dari keluarga. Orang tua (ayah dan ibu) merupakan sasaran utama dalam pencegahan suatu penyakit. Orang tua sebagian besar 
memiliki peran yang cukup dalam mencegah Pneumonia. Berikut upaya pencegahan yang dilakukan masyarakat :

Pemberian ASI Eksklusif

Pencegahan non imunisasi yang dilakukan masyarakat adalah dengan pemberian Air Susu Ibu (ASI) ekslusif.

Memberi asupan makanan yang bergizi dan menjauhkan dari asap rokok dan jenis asap lainnya

Pemberian nutrisi yang baik, penghindaran pajanan Asap rokok, Asap dapur, perbaikan lingkungan hidup dan sikap hidup sehat juga dapat dilakukan masyarakat untuk mencegah kekambuhan penyakit Pneumonia.

Menjaga kebersihan lingkungan sekitar setiap hari

Menjaga lingkungan yang sehat merupakan upaya masyarakat untuk mencegah penyakit dan/atau gangguan kesehatan dari faktor risiko lingkungan untuk mewujudkan kualitas lingkungan yang sehat baik dari aspek fisik, kimia, biologi, maupun social.

\section{PENUTUP}

Gambaran Surveilans meliputi Analisis data surveilans menunjukkan, kasus pneumonia maksimal terjadi pada bulan Oktober tahun 2016 yaitu dengan 30 kasus, wilayah dengan kasus pneumonia yang tinggi yaitu Arcawinangun dengan 56 kasus. Kasus pneumonia banyak menyerang balita dengan usia 1-5 tahun 178 kasus.

Rekomendasi yang dilakukan dapat berupa, pencegahan kesakitan pneumonia pada golongan usia balita (1-5 thn) perlu ditingkatkan dan peningkatan mutu pelayanan.

Kelengkapan laporan belum mencapai target yaitu $80 \%$, ketepatan laporan masih terdapat beberapa wilayah yang dalam kategori lambat dan tidak lapor.

Gambaran Epidemiologi Kasus pneumonia paling banyak terjadi pada penderita laki-laki dengan usia 1-5 tahun. Kasus pneumonia banyak menyerang di wilayah kelurahan Arcawinangun.

Data lingkungan rumah penderita pneumonia paling banyak yang tidak memenuhi syatat yaitu ventilasi rumah yang kurang dari $10 \%$ dan Pencahayaan rumah.

Waktu terjadi kasus pneumonia paling tinggi terjadi di Bulan April.

Gambaran upaya pengendalian yang dilakukan Puskesmas yaitu meliputi Penyuluhan kesehatan kepada masyarakat/bulan, Penyuluhan kepada ibu balita, Melakukan pengobatan, Perbaikan imunisasi pada bayi dan balita dan upaya yang dilakukan Masyarakat yaitu Pemberian ASI Eksklusif, Memberi asupan makanan yang bergizi dan menjauhkan dari asap rokok dan jenis asap lainnya dan Menjaga kebersihan lingkungan sekitar setiap hari untuk mewujudkan kualitas lingkungan yang sehat baik dari aspek fisik, kimia, biologi maupun social.

Saran yang dapat diberikan Bagi Masyarakat Wilayah kerja Puskesmas I Purwokerto timur yaitu melakukan lima imunisasi dasar lengkap bagi masyarakat khususnya bayi/balita yang belum diberi vaksin/imunisasi secara lengkap dan memberi asupan makanan yang bergizi. Hal tersebut dilakukan untuk menjaga daya tahan tubuh supaya tubuh tetap terjaga dari kuman penyebab penyakit, serta agar angka kesakitan Pneumonia dapat dicegah dan ditanggulangi dengan baik.

Masyarakat yang akan membangun rumah atau merenovasi rumah perlu memperhatikan aspek persyaratan rumah sehat yaitu luas ventilasi minimal $10 \%$ daru luas lantai, memasang genteng yang terbuat dari kaca agar pencahayaan dalam ruangan dapat memenuhi syarat.

Saran yang dapat diberikan Bagi Puskesmas I Purwokerto Timur yaitu meningkatkan penyuluhan bagi ibu yang mempunyai balita dengan cara memberikan penyuluhan tentang Pneumonia setiap ada kegiatan posyandu, setiap datang ke Puskesmas dan membagikan leaflet tentang penyakit Pneumonia.

Peningkatan penyuluhan tentang penyakit Pneumonia, ASI ekslusif, gizi balita dan pentingnya imunisasi serta menggerakkan masyarakat dalam kegiatan posyandu dengan cara peningkatan partisipasi kader posyandu sehingga dapat meningkatkan status imunisasi dan perbaikan status gizi pada balita.

Saran yang dapat diberikan Bagi Ibu Balita Yaitu diharapkan ibu balita dapat mengetahui cara deteksi dini penyakit pneumonia dan menerapkan berbagai cara upaya pencegahan pneumonia, meningkatkan pengetahuan tentang pencegahan penyakit pneumonia yaitu membaca dengan aktif.

\section{DAFTAR PUSTAKA}

Albertus, Ata Maran.2013.Penggunaan bahan bakar dan faktor risiko kejadian Ispa Pada Balita di Kelurahan Sikumana.Poltekkes Kemenkes Kupang: Jurnal info Kesehatan.

Anonim, Etiologi penyakit pneumonia.http//:ejurnal.com.diakses pada tanggal 22 Desember 2017 pukul 09.54 WIB.

Arias, Kathleen Meeehan.2010.Investigasi dan pengendalian wabah di Fasilitas Pelayanan Kesehatan.Jakarta: Kedokteran EGC. 
Corry, Wahyuni Hidayat, Suhartono.2016. Hubungan Kondisi Lingkungan Fisik Rumah Dengan Kejadian Pneumonia Pada Balita Di Wilayah Kerja Puskesmas Jatibarang Kabupaten Indramayu.Semarang.Jurnal Kesehatan Masyarakat Undip.

Departemen Kesehatan. Profil Kesehatan Indonesia Tabel 6.9. Tahun 2017.

Depkes RI. 2002. Pedoman Pemberantasan Penyakit ISPA pada Balita.Jakarta:Depkes RI.

Diah, Andriana Rachmawati.2013.Faktor Risiko yang Berhubungan Dengan Kejadian Pneumonia Pada Balita Umur 12-48 Bulan Di Wilayah Kerja Puskesmas Mijen Kota Semarang.Semarang.Jurnal Kesehatan Masyarakat Undip.

Dian, Rahayu Pamungkas.2007.Analisis Faktor Risiko Pneumonia Pada Balita Di 4 Provinsi Di Wilayah Indonesia Timur.Jakarta.Fakultas Kesehatan Masyarakat UI.

Dinas Kesehatan Kabupaten Banyumas. Profil Kesehatan Kabupaten Banyumas Tabel 6.9.Tahun 2016.

Heru, Podomonobo, Onny, dkk.2012.Hubungan Faktor Lingkungan Fisik Rumah Dengan Kejadian Pneumonia Pada Balita Di Wilayah Kerja Puskesmas Jatibarang Kabupaten Brebes.

Jurnal Kesehatan Indonesia Kementerian PPN/Bappenas. Rencana Pembangunan Jangka Panjang Nasional Tahun 20052025.
Kepmenkes RI NO 829/MENKES/ SK/ VII/1999 Tentang Persyaratan Kesehatan Perumahan.

Koes, Irianto.2014.Epidemiologi penyakit menular dan tidak menular panduan klinis.Bandung: ALFABETA, CV.

Kuswiyanto.2017.Bakteriologi 2. Jakarta: Kedokteran EGC.

Misnadiarly.2008.Pneumonia: Pada Anak Balita, Orang Dewasa dan Usia Lanjut.Jakarta.Yayasan Obor Indonesia.

Permenkes RI No 1077/Menkes/PER/V/2011 Tentang Pedoman Penyehatan Udara Dalam Ruang Rumah.

Qorry, 'Aina Abata.2014.Ilmu Penyakit Dalam.Madiun: Yayasan PP Al-Furqon.

Tatag, Fajar.2010. Karya tulis ilmiah Tinjauan epidemiologi penyakit infeksi SaluranPernafasan akut (ispa) di desa sambeng wetan Kecamatan kembaran kabupaten Banyumas Tahun 2010.Purwokerto: Politeknik Kesehatan Depkes Semarang Jurusan Kesehatan Lingkungan Purwokerto.

WHO \& UNICEF.2006.Pneumonia:The forgotten killer of children.New York: WHO \& UNICEF.

Zulfa, Kamalia Amin.2015. Faktor risiko yang berhubungan dengan kejadian Pneumonia Berulang pada Balita di Wilayah kerja Puskesmas ngesrep Kota Semarang Tahun 2014.Semarang:Jurusan Ilmu Kesehatan Masyarakat Fakultas Ilmu Keolahragaan Universitas Negeri Semarang. 